\title{
Chapter 18 \\ Fostering the Sustainability and Scalability of Curriculum Innovations Through Collaborative Design
}

\author{
Marie A. B. Bakah, Kassimu A. Nihuka, and Arkato Gendole Anto
}

\section{Introduction}

The premise behind collaborative curriculum design in teacher teams is that it in effective strategy for teachers' professional development and sustainable innovation of curricula (Voogt, Pieters, \& Handelzalts, 2016). In this chapter three small-scale studies in higher education are presented in which teachers collaboratively (re-)designed their curricula in teams. As researchers involved in the three studies, we wanted to know whether and why the teacher design teams that participated in the respective studies continued to exist, and whether their products (the curricula) were still in use. In addition, we were interested in the factors that contributed to whether the teams continued or not and the potential for scaling up the approach within the respective institutions. This chapter discusses these three studies, which focused on examining the sustainability and scalability of teacher design teams in different contexts. We conceptualized sustainability as the continuation of teacher design teams in terms of the approach (collaborative design in teacher teams) and the use of the materials produced by the design teams (courses, teacher guides, hand-outs, etc.). We conceptualized scalability as the expansion of teacher design teams within the institution.

The context of the first study involved updating the curriculum of polytechnics in Ghana, the second study's context involved the implementation of e-learning in the

\footnotetext{
M. A. B. Bakah $(\bowtie)$

Institute for Educational Planning \& Administration, University of Cape Coast, Cape Coast, Ghana

A. G. Anto

School of Graduate Studies, Arba Minch University, Arba Minch, Ethiopia 
Open University of Tanzania, and the third study addressed the implementation of communicative English language teaching at a university in Ethiopia. The main question for all three studies concerned the potential sustainability and scalability of teacher design teams, the effects on professional development of its members and the contribution to educational change.

\section{Theoretical Underpinnings}

\section{Sustainability}

The term sustainability implies the continuation of a programme in some way. Stoll, Bolam, McMahon, Wallace, and Thomas (2006) used sustainability to represent elements of continuous growth that are necessary for change, where emphases can include whether the focus is on continuation of the benefits of the programme to the stakeholders/participants; the perseverance of the new initiative itself; or the process of developing local capacity to enable a programme to be maintained at the stakeholder/institution level. Sustainability may constitute a distinct stage of programme development in recognition of particular requirements for sustained use in the areas of, for example, training (Elias, Zins, Graczyk, \& Weissberg, 2003; Osganian, Parcel, $\&$ Stone, 2003). It has also been suggested that the process of programme development (including sustainability) cannot be understood in isolation from the context in which the programme is operating (Goodson, Murphy-Smith, Evans, Meyer, \& Gottlieb, 2001; Harvey \& Hurworth, 2006). From this position, actions undertaken to initiate sustained use are mediated through the different structures and practices within individual settings and so create a unique set of factors for establishing sustainability. Further, it has been indicated that the necessary conditions required for sustainability need to be planned for at the early stages of programme development (Paine-Andrews, Fisher, Campuzano, Fawcett, \& Berkley-Patton 2000). Therefore, these understandings tend to suggest that sustainability may develop from a more interactive relationship between the different stages of programme development and may not be based on a simple linear process (Harvey \& Hurworth, 2006).

From a more general perspective, sustainability of educational innovations involves maintaining improvement over time, learning gains for everyone and not just a few, support by attainable or available resources and opportunities for diverse solutions and flexibility (Hargreaves \& Fink, 2000). On a system level, the sustainability of a professional development programme is demonstrated by the extent to which the professional development concept is accepted and implemented by different schools in an administrative region persistently (Todorova \& Osburg, 2009). Necessary conditions for sustainability are the participation in the programme of a large proportion of the teachers in schools, teachers' positive attitudes and satisfaction with the professional development programme, availability of support and transfer of the goals, content and methodology of the programme (Todorova \& Osburg, 2009). 


\section{Scaling Up}

After decades of intense educational reform, educators, policymakers, and researchers still grapple with the question of how pockets of successful reform efforts might be "scaled up." Most research on scalability tends to define what it means to "scale up" an external reform in quantitative terms, focusing on increasing the number of teachers, schools, or districts involved (Coburn, 2003; Datnow, Hubbard, \& Mehan, 2002; Hargreaves \& Fink, 2000; Legters, Balfanz, Jordan, \& McPartland, 2002). Stringfield and Datnow (1998) defined scaling up as 'the deliberate expansion to many settings of an externally developed school restructuring design that previously has been used successfully in one or a small number of school settings' (p. 271). Despite this simple definition, Coburn (2003) stated that it says nothing about the nature of the change envisioned or enacted or the degree to which it is sustained, or the degree to which schools and teachers have the knowledge and authority to continue to grow the reform over time. While the idea of sustainability is fundamental to scale-up, few conceptualizations address it explicitly. It only rarely appears in theoretical and empirical pieces (McLaughlin \& Mitra, 2001). Most discussions address issues of sustainability and scalability separately, obscuring the way that scalability, in fact, depends upon sustainability (Coburn, 2003). There is ample evidence that sustainability may be the central challenge of bringing reforms up to scale. Schools that successfully implement reforms find it difficult to sustain them in the face of competing priorities, changing demands, and teacher and administrator turnover (Berends, Bodilly, \& Kirby, 2002; Hargreaves \& Fink, 2000; Hatch, 2000; McLaughlin \& Mitra, 2001). Scaling up involves adapting an innovation that is successful in a local setting to effective usage in a wide range of contexts (Dede, 2006). In contrast to experiences in other sectors of society, scaling up successful programmes is very difficult in education (Dede \& Honan, 2005). Scalable designs for educational transformation must avoid what Wiske and Perkins (2005) term the 'replica trap': the erroneous strategy of trying to repeat everywhere what worked locally, without taking account local variations in needs and environments. For example, the one-size-fits-all model does not fit when scaling up in education, because a pedagogical strategy that is successful in one particular classroom setting with one particular group of students frequently will not succeed in a different classroom with different students. This suggests the need for a renewed and vigorous dialogue, not just about the challenges of sustainability, but about strategies for providing schools with the tools they will need to sustain the reform (Coburn, 2003). Dede and Honan (2005) identify four key themes in adapting an educational innovation that is success in some local setting to effective usage in wide range of contexts:

1. Coping with change: context, leadership, and funding.

2. Promoting ownership: building constituent support; institutionalizing innovations.

3. Building human capacity: working with collaborators and partners; providing professional development.

4. Effective decision making: interpreting data; creating and applying usable knowledge. 
In the context of innovations in teaching/curriculum, Coburn (2003) describes scalability as encompassing four interrelated dimensions: depth, sustainability, spread, and shift in reform ownership. "Depth" refers to deep and consequential change in classroom practice, altering teachers' beliefs, norms of social interaction, and pedagogical principles as enacted in the curriculum. "Sustainability" involves maintaining these consequential changes over substantial periods of time, and "spread" is based on the diffusion of the innovation to large numbers of classrooms and schools. "Shift" requires districts, schools, and teachers to assume ownership of the innovation, deepening, sustaining, and spreading its impacts. A fifth possible dimension to extend Coburn's framework is "evolution," in which the innovation as revised by its adapters is influential in reshaping the thinking of its designers, creating a community of practice that evolves the innovation (Dede, 2006). The explicit focus on sustainability as a key element of scalability also has implications for research design (Coburn, 2003). Other studies in the literature on scalability employ designs that sample schools with a range of years of experience participating in the reform (Datnow, Borman, \& Stringfield, 2000). In particular, design for sustainability centres on the issue of contextual variation and involves designing educational innovations to function effectively across a range of relatively inhospitable settings (Dede, 2006). Placing reform ownership as a central element of scalability raises the priority for directing reform attention and resources to strategies that have the potential for enabling schools and districts to assume ownership of the reform over time (Coburn, 2003).

\section{Factors Affecting Sustainability and Scalability}

Factors required for successful scaling up of an innovation resemble factors that are important for sustainability of innovations (Fullan, 2007; Hoven, 2000; Means \& Penuel, 2005; Sife, Lwoga, \& Sanga, 2007). These factors can be categorized as: external factors outside the control of the organisation, institutional factors and conditions related to internal adoption (Ten Brummelhuis, 1995).

External factors are factors outside the control of the organization and difficult to alter by the organization. State and national policies are among the external factors that may promote or hinder the implementation, continuation and scalability of an innovation such as collaborative design in teacher teams (Guskey, 2000; Hord \& Summers, 2008).

Institutional factors refer to the existence of organizational policies supporting the proposed innovation, the arrangement of professional and administrative assistance for the teachers, and resources and strategies for monitoring the implementation. There needs to be a careful alignment between different management levels and between the management and the majority of the instructors regarding 
implementation of the innovation (Dexter, 2007; Fullan, 2007). According to Fullan (2007), the management is in a position to shape the organizational conditions, such as the development of shared goals and the climate for collaboration. Having management that foresees and provides appropriate professional development for instructors is also essential for effective sustainability and scaling up of an innovation (Arabasz \& Baker, 2003; Joint, 2003). According to Walker and Johnson (2008), training should be regularly provided so as to accommodate new and inexperienced instructors.

Conditions for internal adoption refer to relevance, readiness, and resources (Fullan, 1991). Relevance refers to stakeholders' opinions about the importance of the innovation. The way the teachers perceive the relevance of a professional development program affects their sense of ownership of the program, and this perception enhances or limits the teachers' interest in learning about the program and in using it as intended in their classroom teaching practices (Elias et al., 2003). The goals of a professional development effort should be worthwhile for stakeholders (Guskey, 2000). Readiness includes the stakeholders' potential ability to implement and continue an innovation, including the necessary knowledge, attitudes and skills of individual practitioners (Steyn, 2005), Instructors' positive attitude contributes to their willingness and in fact is key to the sustainability and scalability of an innovation (Walker \& Johnson, 2008). The issue of instructors' perceptions of the practicality of the innovation is similarly crucial (Doyle \& Ponder, 1978). Resources represent the availability of the financial support, time, equipment and materials required to realize the intended change. Effective support for instructors plays a role in the sustainability and use of innovations (Sife et al., 2007). With support, instructors find scaling up of innovation, such as e-learning, easier and more interesting (Walker \& Johnson, 2008). Lim and Khine (2006) found that instructors are more likely to be motivated both intrinsically and extrinsically if they are offered incentives. Incentives include providing monetary rewards, reducing the workload of instructors (Leem \& Lim, 2007), providing materials, such as a laptop (Stoltenkamp, Kles, \& Njenga, 2007), and opportunities for educational scholarship and professional development (Brent, Felder, Hirt, Sitzer, \& Holzer, 1999). Steyn (2005) contended that availability of resources enabling teachers to effectively implement the innovation in their classroom practices is considered an essential factor for continued use of program as intended. In particular, an appropriate ICT infrastructure is required in e-learning innovations (reported in the second study). This implies access to computers, internet, learning management systems, e-mail and mobile phones, and so forth (Sherry \& Gibson, 2002; Siritongthaworn, Krairit, Dimmitt, \& Paul, 2006). Challenges such as narrow bandwidth, unreliable and frequent power outages (Cuban, Kirkpatrick, \& Peck, 2001; Gakio, 2006; Siritongthaworn et al., 2006) also interfere with the sustainability and scalability of e-learning innovations. 


\section{Study 1: Ghana: Collaborative Curriculum Re-design of the Polytechnic Curriculum}

\section{Context}

In 2007, polytechnic institutions in Ghana became higher institutions of vocational learning by law, and could offer Bachelor of Technology programs as well as Higher National Diplomas. As a result, Ghanaian polytechnics embarked on rigorous curriculum reform. A major challenge faced by the polytechnics was the professional development of teachers, as curriculum design became their responsibility. This study employed a collaborative approach to curriculum design to support teachers in redesigning the curriculum. The use of collaborative curriculum design was used in this study due to its workable, cohesive and interactive nature and as an effective professional development strategy among teachers. Two iterations of the intervention were developed and tested. The intervention lasted 12 weeks and consisted of an introduction and dissemination workshop, design meetings to update courses, visits to industry sites and a teaching try-out.

The impact study focused on the sustainability and the potential for large-scale implementation of design teams in the two polytechnics studied. This sustainability study was conducted 18 months after implementation of the first intervention study and 8 months after implementation of the second intervention study. Teachers $(n=29)$ participating in the intervention, teachers not participating in the intervention $(n=34)$ and management $(n=8)$ shared their insights and reflections on the programme and the way ahead for teacher learning in the polytechnic. Data collection took place though a questionnaire, individual interviews and focus group interviews.

\section{Main Findings}

The results showed that teachers continued to collaborate in design teams for curriculum design and professional development and that new design teams had started in other departments. The continuation of the existing design teams (sometimes with new members joining the team) and the formation of new design teams in other departments indicate the potential for sustainability and scalability of teacher design teams within Ghana's polytechnics. Leaders' activities and behaviours were identified as supporting the sustainability of design teams. The findings showed that scaling up design teams within the polytechnics seemed promising due to supportive factors such as the maintenance and expansion of original design teams and staff awareness and commitment within the institutions. The sustainability of design teams in the long run, however, needs to be better regulated and incorporated in the 
polytechnic structure (institutional factors). Some identified inherent opportunities for supporting sustainability are outlined and conclusions drawn based on the characteristics of the programme, contextual features and polytechnic climate. An opportunity presented by collaborative design in teacher teams is that working collaboratively on authentic design tasks holds prospects for teachers to address their learning needs (internal adoption conditions). The characteristics of the programme also contributed to the continued use of design teams. For instance, the underlying design of design teams emphasised teacher and leadership involvement and ownership, identification of learning needs, links with existing policies and structures regarding curriculum design and an already recognised need for teacher development to support the polytechnic reform process. Using evidence-based research promoted the understanding of best practices in teamwork among teachers, together with current knowledge about design team usage for collaborative curriculum design. The already collegial relationship that characterises design teams enhanced a normative change and provided continuing opportunities to learn.

\section{Study 2: Tanzania: Collaborative Course Redesign to Support E-Learning Implementation}

\section{Context}

Distance education at the Open University of Tanzania (OUT) is dominated by a print-based mode of delivery. Because of that, several challenges confront instructors and students at OUT, which include (i) delays in the delivery of print study materials, course outlines and learning resources; (ii) lack of regular interaction between instructors and students; (iii) lack of immediate feedback on student learning and (iv) feelings of isolation among students.

Studies from developed countries show that e-learning technologies are used in distance education to enhance the delivery of courses, facilitate access to resources, improve interactions with students and provide feedback and support to students (e.g., Ludwig-Hardman \& Dunlap, 2003; Pena-Bandalaria, 2007). Recognizing the potential of e-learning, in 2004, OUT embarked on supporting instructors' professional development through workshops. Despite the workshops, instructors at OUT continued to deliver their courses traditionally. Collaborative Course Design in design teams was applied as a strategy for effective professional development in preparing instructors regarding course (re-)design and delivery of courses using the Moodle learning management system. Collaborative Course Design had the following characteristics: active participation of instructors, maintenance of activities over a long period of time, opportunities for collaboration within and between design teams and support for instructors. In this way instructors' ownership of e-learning 
was promoted, which was assumed to contribute to e-learning implementation at OUT. Two iterative cycles of Collaborative Course Design were implemented during a 2-year period.

The impact study investigated the feasibility for incorporating collaborative curriculum design as a strategy for professional development of instructors regarding e-learning implementation within OUT at a larger scale. Five representatives from the management participated in the study, including the vice-chancellor, four deans and one director. Fifteen instructors who participated in collaborative curriculum design during the pilot and implementation study and 20 instructors not previously involved in collaborative curriculum design participated in the study. Data collection through interviews and a questionnaire took place 6 months after the last cycle of Collaborative Course Design.

\section{Main Findings}

Findings revealed that several opportunities made the implementation of large-scale collaborative curriculum design at OUT to support instructors regarding e-learning implementation at a large scale feasible. The management at all levels was committed to and interested in e-learning course delivery, found it useful and felt that it contributed to the improvement of students' enrolment and access to distance education. The university had in place an ICT steering committee that included deans and directors as members; the university was also introducing the positions of deputy vice-chancellor in charge of learning technologies and director of educational technology (institutional factors). There existed a comprehensive ICT policy, an ICT master plan and an ICT implementation strategy, which were well aligned to the rolling strategic plan of the university (institutional factors). Results also showed that there was (limited) access to technologies such as computers, internet, phones, printers and photocopiers for instructors in the university. Moreover, the university had in place an incentive scheme which included awards of $\$ 500$, a recognition letter and/or covering expenses to participate in an e-learning conference. There was also centralized technical support within OUT (conditions for internal adoption).

Several challenges were identified that need the attention of the management in order to make scaling up of collaborative curriculum design effective and sustainable at OUT. These include needs for more shared goals regarding e-learning course delivery so that instructors in faculties and institutes consider e-learning as a priority, and alignment of different management levels with instructors in faculties/institutes so that e-learning implementation plans are reflected in the action plans of faculties and institutes (conditions for internal adoption). Other challenges are limited access to technologies, narrow bandwidth, unreliable electricity and lack of well-structured pedagogical support at the university (conditions for internal adoption).

It was concluded that the available opportunities are likely to support large-scale implementation of collaborative curriculum design for large-scale implementation of e-learning at OUT. 


\section{Study 3: Ethiopia: Collaborative Teacher Professional Development for Communicative Language Teaching}

\section{Context}

In Ethiopia, where English serves as a medium of instruction in secondary and higher education, the quality of English teaching is challenged due to a vast and rapid educational expansion and limited teacher quality in higher education. Given the large number of students attending higher education, universities cannot attract sufficient well-qualified academic staff and are compelled to recruit many underqualified English language teachers at the bachelor level who have little or no preservice teacher education and prior teaching experiences. Instruction by under-qualified English language teachers is believed to negatively affect students' English language learning. In addition, the command of English of most students enrolling in higher education is inadequate. Students need to use the English language for daily communication purposes, and therefore they need to learn the language in an interactive way, which is fostered by a student-centered approach to language teaching. Moreover, in line with the existing educational reform, which calls for the use of student-oriented teaching methods, the universities need to move the teachers from a predominantly teacher-dominated language teaching approach to interactive student-centred language teaching that encourages students to use the language for meaningful daily communication purposes. Communicative language teaching (CLT) is widely accepted and believed to be effective in enabling students to learn a language for their authentic communication in an interactive way. The main purpose of this study was to design and implement a collaborative professional development program (CPDP) that would enable Ethiopian higher education English language teachers to enhance their CLT knowledge and practices. Two iterative cycles of the CPDP were developed and implemented over a period of 2 years at Arba Minch University.

A cross-sectional mixed method design was used. Teachers participating in CPDP (PT, $n=16$ ), non-participating teachers (NPT, $n=23$ ), facilitators $(n=3)$ and the management $(n=2)$ provided data for the study. The non-participating teachers included teachers who did not participate in the formal implementation of the professional development program, but taught the course Communicative English Skills assisted by the products of the CPDP: the teacher guides, the CLT hand-out and the revised learner materials.

\section{Main Findings}

With regard to the external conditions, the study found that the government did formulate policies to encourage in-house professional development of teachers at Ethiopian universities. These policies laid good groundwork for continued use of the CPDP elements, as policies create a framework for action. Universities, 
however, have paid limited attention to these initiatives and focused on making the teachers pursue further study to obtain higher qualifications. Fortunately, the college dean demanded that teachers participate in ongoing professional development and that the CPDP be included in the English Language Improvement Program. This means that there will be sufficient managerial support to continue using the CPDP elements.

From the perspective of conditions for internal adoption, teachers, facilitators and management perceived CPDP as a relevant program and all PTs and NPTs found the hand-out, the teacher guides and teacher collaboration relevant. PTs perceived the hand-out as more relevant than NPTs did, a statistically significant difference. Teachers used the CLT hand-out and the teacher guides in more than half of their lessons. PTs were found to use these materials better than NPTs, but the difference was not significant. The PTs' better perception of the CLT hand-out and better use of the handout and the teacher guide can be explained by the fact that PTs had better exposure to the materials during their CPDP training sessions. Possibly because of experiencing collaboration during the actual CPDP implementation, PTs continued to use teacher collaboration better than NPTs did after the termination of the program. NPTs showed greater variability (larger standard deviations) in their perceptions and use of the CLT hand-out and teacher guides than did PTs. This can be attributed to greater variability in qualifications and teaching experience among NPTs compared to among PTs. To support teachers in their CLT practice, audio materials, learner materials, the teacher guides and the CLT hand-out designed in the previous studies were further developed and made available for use. However, lack of up-to-date books, magazines and journals on CLT and a dysfunctional language lab hampered CLT implementation.

The study shows that teachers are ready to receive and provide assistance (institutional factors) in enhancing their CLT application. Facilitators expressed their willingness to take up their leadership roles if the management arranges for it (e.g., allocating time, extra payment). Stakeholders suggested different strategies to continue and extend peer support as a means to enhance CLT teaching practice. These strategies included: (1) arranging training on peer coaching, (2) regular monitoring and evaluation of the peer coaching processes by facilitators, (3) preparing experienced teachers (facilitators) to train teachers on various aspects of peer coaching, (4) pairing up teachers teaching similar courses, (5) making it possible for teachers to share similar offices, (6) providing necessary materials, (7) allocating sufficient time, (8) recruiting professional development leaders and facilitators, and (8) providing financial rewards for staff involved in various professional development undertakings.

The study further reveals that the college plans to put the CPDP under the English Language Improvement Program (ELIP) to continue the program. The department head had the learner materials for the course Communicative English Skills revised and sent the learner materials, the hand-out and the teacher guide to the teachers. In addition, a committee monitoring teachers' use of the materials has been established, and laptops have been provided to teachers lacking their own to teach listening skills. 
To conclude, the CPDP has made important contributions to the professional development of English language teachers at Arba Minch University. First, English language teachers perceive the materials (hand-out and teacher guides) developed as part of the CPDP to support them in their teaching as relevant and they are ready to use them. The absence of a significant difference between PTs and NPTs in terms of their perception and effective use of most of the CPDP elements implies that the program and its elements are useful for both teacher groups for successful learning and implementation of CLT. The importance of reading materials (Joyce \& Showers, 2002), teacher guides (Thijs \& Van den Berg, 2002) and concrete resources such as audio texts (Richards \& Farrell, 2005) as part of professional development has also been found in other studies, in which they are seen as productive tools to enhance teachers' professional learning and facilitate curriculum enactment (Garet, Porter, Desimone, Birman, \& Yoon, 2001). Second, English language teachers are open to initiatives that encourage teacher collaboration and peer support, to enhance their CLT skills further. These findings indicate that teachers feel committed to the implementation of CLT (Fullan, 2007). The better use of teacher collaboration by PTs than NPTs implies that in order to use collaboration in their teaching practices effectively, teachers should participate in a professional development initiative in which collaboration is an integral part. Third, the importance put on continuing professional development in national and university policies offers opportunities to develop strategies to promote teacher collaboration and peer support as professional development strategies for English language teachers. These findings suggest that bottom-up and top-down strategies to support the implementation of CLT are in balance (Fullan, 2007).

For continuing use of the CPDP elements, it is crucial to have in place a system embedded at the university that is responsible for: (a) keeping the teacher guides and the hand-out up to date, (b) distributing these materials to teachers, (c) encouraging and scaffolding teachers to collaborate and support each other in their classroom teaching. Other universities in the country could model this system.

\section{Reflections}

The three studies presented in this chapter have shown that teacher design teams contribute to sustainable outcomes and have potential for scaling up of curriculum innovations and teacher professional development. In all three studies, the products of teacher design teams were still in use; in two of the three studies (at Ghana's Polytechnics and the Open University of Tanzania) teacher design teams had also continued to exist as an approach to professional development and curriculum innovation. Scaling up of the approach was considered feasible in Ghana's polytechnics and the Open University of Tanzania.

Teachers' appreciation of collaboration as a means to encourage teacher learning through collaborative discussion, sharing and reflection on their common issues and practical experiences is consistent with the views of many scholars (Harvey \& 
Hurworth, 2006; Little, 1990) who take teacher collaboration as a vital instrument for enhancing teacher learning. Most teachers had a clear commitment to continual improvement and saw the design teams as a useful means for this process. Despite this fact, the teachers at the Open University in Tanzania and at Arba Minch University in Ethiopia mentioned that they engaged in limited practice of collaboration, which they attributed to a shortage of common time to get together and jointly carry out these activities. The poor culture of collaboration among teachers could threaten the sustainability of teacher design teams (Fisher \& Swindells, 1998). We are, however, conscious of the fact that the process of re-culturing is a long-term journey, as evidenced by the time, energy and resources exerted to move from implementation to sustainability.

Committed management, conducive institutional conditions and support structures fostered the continuation of teacher design teams at the Open University of Tanzania and Ghana's polytechnics. The most important supportive contextual feature for sustained design team use generally involved the leaders' support. The teachers' enthusiasm was boosted when some leaders encouraged the formation of new design teams in Ghana's polytechnics. External conditions hampered the continuation of teacher design teams in Ethiopian universities. An important reason was that the universities pressured teachers to obtain higher qualifications outside the university, leaving little room for in-house professional development. However, the outcomes of teacher design teams at the Ethiopian university, the learner material for the course Communicative English Skills, was provided to the teachers. In addition, a committee monitoring teachers' use of the materials has been established, and laptops have been provided to teachers lacking their own to teach listening skills. At the Open University the non-existence of (e-learning) action plans at the level of faculties/institutes indicates a need for better alignment between plans at university and faculty/institute level, which is necessary for teacher design teams to be sustainable in the long run. Similarly, the need to incorporate teacher design teams in the policy structure of Ghana's polytechnics also shows the vulnerability of the innovation at the department and institution level.

The underlying design of design teams emphasised teacher and leadership involvement and ownership, identification of learning needs, links with existing policies and structures regarding curriculum design and an already recognised need for teacher development to support the polytechnic reform process. An additional feature that also appeared to assist with the continued use of design teams was the use of evidence-informed research in the development of the programme. Understandings of best practices in teamwork among teachers were combined with current knowledge about usage of design teams for collaborative curriculum design. The use of this broad theoretical underpinning appeared to strengthen the specific design of the strategies for planning and implementing collaborative curriculum design through design teams. The components of collaborative curriculum design were set within a purposeful and tangible process of curriculum reform in all three contexts. 


\section{References}

Arabasz, P., \& Baker, M. (2003). ECAR respondent summary: Evolving campus support models for e-learning courses. Retrieved May 12, 2006, from http://www.educause.edu/ir/library/pdf/ ERS0303/ekf0303.pdf

Berends, M., Bodilly, S., \& Kirby, S. N. (2002). Facing the challenges of whole-school reform: New American schools after a decade. Santa Monica, CA: Rand.

Brent, R., Felder, R. M., Hirt, D., Sitzer, D., \& Holzer, S. (1999). A model program for promoting effective teaching in colleges of engineering. Proceedings of the 1999 annual ASEE meeting, ASEE, June, 1999.

Coburn, C. E. (2003). Rethinking scale: Moving beyond numbers to deep and lasting change. Educational Researcher, 32(6), 3-12.

Cuban, L., Kirkpatrick, H., \& Peck, C. (2001). High access and low use of technology in high school classrooms: Explaining an apparent paradox. American Educational Research Journal, 38(4), 813-834.

Datnow, A., Borman, G., \& Stringfield, S. (2000). School reform through a highly specified curriculum: Implementation and effects of the core knowledge sequence. The Elementary School Journal, 101(2), 167-191.

Datnow, A., Hubbard, L., \& Mehan, H. (2002). Extending educational reform: From one school to many. London: Routledge/Falmer.

Dede, C. (2006). Scaling up: Evolving innovations beyond ideal settings to challenging contexts of practice. In R. K. Sawyer (Ed.), Cambridge handbook of the learning sciences (pp. 551-566). Cambridge, UK: Cambridge University Press.

Dede, C., \& Honan, J. P. (2005). Scaling up success: A synthesis of themes and insights. In C. Dede, J. P. Honan, \& L. Peters (Eds.), Scaling up success: Lessons learned from technologybased educational improvement (pp. 227-239). New York: Jossey-Bass.

Dexter, S. (2007). Show me the leadership: The impact of distributed technology leadership teams' membership and practices at four laptop schools. Paper presented at the 88th Annual Meeting of the American Educational Research Association, Chicago, IL.

Doyle, W., \& Ponder, G. (1978). The practicality ethic in teacher decision making. Interchange, $8(3), 1-12$.

Elias, M. J., Zins, J. E., Graczyk, P. A., \& Weissberg, R. P. (2003). Implementation, sustainability, and scaling up of social-emotional and academic innovations in public schools. School Psychology Review, 32(3), 303-319.

Fisher, R., \& Swindells, D. (1998). The development priorities of Ethiopian higher education teachers. Journal of In-Service Education, 24(2), 307-315.

Fullan, M. (2007). The new meaning of educational change. New York: Teachers College Press.

Fullan, M. G. (1991). The new meaning of educational change (2nd ed.). New York: Teachers College Press.

Gakio, K. (2006). African tertiary institutions connectivity survey. Report commissioned by the International Development Research Centre of Canada. Retrieved from http://www.aau.org/ renu/docs/ATICS2006.pdf on 20th September, 2009.

Garet, M. S., Porter, A. C., Desimone, L., Birman, B. F., \& Yoon, K. S. (2001). What makes professional development effective? Results from a national sample of teachers. American Educational Research Journal, 38(4), 915-945.

Goodson, P., Murphy-Smith, M., Evans, A., Meyer, B., \& Gottlieb, N. H. (2001). Maintaining prevention in practice: Survival of PPIP in primary care settings. American Journal of Preventive Medicine, 20(3), 184-189.

Guskey, T. R. (2000). Evaluating teacher professional development. Thousand Oaks, CA: Corwin.

Hargreaves, A., \& Fink, D. (2000). The three dimensions of reform. Educational Leadership, $57(7), 30-34$.

Harvey, G., \& Hurworth, R. (2006). Exploring programme sustainability: Identifying factors in two educational initiatives in Victoria. Evaluation Journal of Australasia, 6(1), 36-44. 
Hatch, T. (2000). What does it take to break the mold? Rhetoric and reality in new American schools. Teachers College Record, 102(3), 561-589.

Hord, S. M., \& Summers, W. A. (2008). Leading professional learning communities: Voices from research and practice. Thousand Oaks, CA: Corwin.

Hoven, K. (2000). A study on the potential of information and communication technologies in university education in Tanzania. A case study of the University of Dar es Salaam (Master of arts thesis). Nijmegen, The Netherlands: Radboud University.

Joint, N. (2003). Information literacy evaluation: Moving towards virtual learning environments. Electronic Library, 21(4), 322-334.

Joyce, B. R., \& Showers, B. (2002). Student achievement through staff development (3rd ed.). Alexandria, VA: ASCD.

Leem, J., \& Lim, B. (2007). The current status of e-learning and strategies to enhance educational competitiveness in Korean higher education. International Review of Research in Open and Distance Learning, 8(1), 1-18.

Legters, N. E., Balfanz, R., Jordan, W. J., \& McPartland, J. M. (2002). Comprehensive reform for urban high schools: A talent development approach. New York: Teachers College Press.

Lim, C. P., \& Khine, M. S. (2006). Managing teachers' barriers to ICT integration in Singapore schools. Journal of Technology and Teacher Education, 14(1), 97-125.

Little, J. W. (1990). The persistence of privacy: Autonomy and initiative in teachers' professional relations. Teachers College Record, 91(4), 509-536.

Ludwig-Hardman, S., \& Dunlap, J. C. (2003). Learner support services for online students: Scaffolding for success. International Review of Research in Open and Distance Learning, $4(1), 1-15$.

McLaughlin, M. W., \& Mitra, D. (2001). Theory-based change and change-based theory: Going deeper and going broader. Journal of Educational Change, 2(4), 301-323.

Means, B., \& Penuel, W. R. (2005). Scaling up technology-based educational innovations. In C. Dede, J. Honan, \& L. Peters (Eds.), Scaling up success: Lessons learned from technologybased educational innovation. New York: Jossey-Bass.

Osganian, S. K., Parcel, G. S., \& Stone, E. J. (2003). Institutionalization of a school health promotion programme: Background and rationale of the CATCHON study. Health Education \& Behavior, 30(4), 410-417.

Paine-Andrews, A., Fisher, J. L., Campuzano, M. K., Fawcett, S. B., \& Berkley-Patton, J. (2000). Promoting sustainability of community health initiatives: An empirical case study. Health Promotion Practice, 1(3), 248-258.

Pena-Bandalaria, M. D. (2007). Impact of ICTs on open and distance learning in a developing country setting: The Philippine experience. International Review of Research in Open and Distance Learning, 8(1), 1-15.

Richards, J. C., \& Farrell, T. S. (2005). Professional development for language teachers: Strategies for teacher learning. New York: Cambridge University Press.

Sherry, L., \& Gibson, D. (2002). The path to teacher leadership in educational technology. Contemporary Issues in Technology and Teacher Education [Online serial], 2(2), 178-203.

Sife, A. S., Lwoga, E. T., \& Sanga, C. (2007). New technologies for teaching and learning: Challenges for higher learning institutions in developing countries. International Journal of Education and Development using Information and Communication Technology, 3(20), 57-67.

Siritongthaworn, S., Krairit, D., Dimmitt, N. J., \& Paul, H. (2006). The study of e-learning technology implementation: A preliminary investigation of universities in Thailand. Education and Information Technologies, 11(2), 137-160.

Steyn, G. M. (2005). Exploring factors that influence the effective implementation of professional development programs on invitational education. Journal of Invitational Theory and Practice, 2, 7-34.

Stoll, 1., Bolam, R., McMahon, A., Wallace, M., \& Thomas, S. (2006). Professional learning communities: A review of the literature. Journal of Educational Change, 7(4), 221-258. 
Stoltenkamp, J., Kles, C., \& Njenga, J. (2007). Institutionalizing the e-learning division at the University of the Western Cape, South Africa. International Journal of Education and Development using Information and Communication Technology, 3(4), 143-152.

Stringfield, S., \& Datnow, A. (1998). Introduction: Scaling up school restructuring designs in urban schools. Education and Urban Society, 30(3), 269-276.

Ten Brummelhuis, A. C. A. (1995). Models of educational change: The introduction of computers in Dutch secondary education. Doctoral dissertation. Enschede, The Netherlands: University of Twente.

Thijs, A., \& Van den Berg, E. (2002). Peer coaching as part of a professional development program for science teachers in Botswana. International Journal of Educational Development, $22,55-68$.

Todorova, A., \& Osburg, T. (2009). Factors for the sustainability of a teacher professional development programme for technology integration. Paper presented at the London International Conference on Education.

Voogt, J., Pieters, J., \& Handelzalts, A. (2016). Teacher collaboration in curriculum design teams: Effects, mechanisms and conditions. Educational Research and Evaluation, 22(3-4), 121-140.

Walker, G., \& Johnson, N. (2008). Faculty intentions to use components for web-enhanced instruction. International Journal on E-Learning, 7(1), 133-152.

Wiske, M. S., \& Perkins, D. (2005). Dewey goes digital: Scaling up constructivist pedagogies and the promise of new technologies. In C. Dede, J. Honan, \& L. Peters (Eds.), Scaling up success: Lessons learned from technology-based educational innovation. New York: Jossey-Bass.

Open Access This chapter is licensed under the terms of the Creative Commons Attribution 4.0 International License (http://creativecommons.org/licenses/by/4.0/), which permits use, sharing, adaptation, distribution and reproduction in any medium or format, as long as you give appropriate credit to the original author(s) and the source, provide a link to the Creative Commons licence and indicate if changes were made.

The images or other third party material in this chapter are included in the chapter's Creative Commons licence, unless indicated otherwise in a credit line to the material. If material is not included in the chapter's Creative Commons licence and your intended use is not permitted by statutory regulation or exceeds the permitted use, you will need to obtain permission directly from the copyright holder.

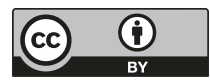

